\title{
Argilas organofílicas: características, metodologias de preparação, compostos de intercalação e técnicas de caracterização
}

\section{(Organophilic clays: characteristics, preparation methods, intercalation compounds and characterization techniques)}

\author{
L. B. de Paiva ${ }^{1}$, A. R. Morales ${ }^{1}$, F. R. V. Díaz ${ }^{2}$ \\ ${ }^{1}$ Departamento de Tecnologia de Polímeros, FEQ, UNICAMP, Av. Albert Einstein, 500, C.P. 6066 \\ Campinas, SP 13083-970 \\ ${ }^{2}$ Departamento de Engenharia Metalúrgica e de Materiais, Escola Politécnica, USP, \\ Av. Prof. Mello Moraes 2463, Cidade Universitária, S. Paulo, SP 05508-900 \\ lucilenebetega@yahoo.com.br,morales@dtp.feq.unicamp.br
}

\begin{abstract}
Resumo
As argilas são materiais muito usados e que atualmente apresentam inúmeras aplicações devido as interessantes propriedades que apresentam. A modificação superficial de argilas é uma área que tem recebido bastante atenção dos pesquisadores porque por meio dos diversos tipos de modificação é possível a preparação de novos materiais e novas aplicações. Este trabalho tem como objetivo apresentar uma revisão bibliográfica sobre argilas organofílicas, especialmente as obtidas a partir de bentonitas e de sais quaternários de amônio. Diversos estudos vêm sendo realizados baseados em diferentes técnicas e parâmetros de síntese desses materiais, incluindo argilas de diferentes regiões e diferentes agentes de modificação, bem como as diferentes aplicações que são propostas.
\end{abstract}

Palavras-chave: argilas, bentonitas, argilas organofílicas.

Abstract

Clays are materials used since historical periods and nowadays have several applications due to their interesting properties. The surface modification of clays is one area that has received enough attention from researchers because through modification it is possible to prepare new materials and find applications. The purpose of this paper is to present a review on the use of clays for obtaining organophilic clays, especially those used in polymeric nanocomposites. Several studies have been done based on different techniques and process conditions of these materials. The review includes clays of different regions, different modification agents and applications.

Keywords: clays, bentonite, organophilic clays.

\section{INTRODUÇÃO}

Argilas são materiais usados pelo homem desde os tempos antigos onde se faziam objetos do tipo "barro cozido" como tijolos, estatuetas, vasos, etc.. Atualmente apresentam uso crescente em inumeráveis aplicações como em fertilizantes, catalisadores, areias de fundição, tijolos refratários, adsorventes, agentes descorantes e clarificantes de óleos e gorduras, tintas, agentes de filtração, cargas para polímeros e elastômeros, papel, etc. [1-4]. Isso ocorre devido à variedade de argilas existentes e também às interessantes propriedades que esses materiais apresentam, como inchamento, adsorção, propriedades reológicas e coloidais, plasticidade, etc.. No entanto, várias dessas aplicações só são possíveis após a modificação superficial das argilas. A modificação superficial de argilas é uma área que tem recebido bastante atenção porque permite ampliar os horizontes de aplicação das argilas, gerando novos materiais e novas aplicações.

$\mathrm{O}$ principal foco de modificação de argilas vem sendo direcionado à ciência dos materiais, cujo objetivo é a obtenção de argilas organofílicas para aplicação em nanocompósitos poliméricos. Diversas rotas podem ser empregadas na modificação de argilas. Essas técnicas incluem: troca de íons por íons de sais quaternários de amônio, adsorção ou interações íon-dipolo, troca de íons com cátions inorgânicos e complexos catiônicos, graftização de compostos orgânicos, reação com ácidos, pilarização com cátions metálicos, polimerização interlamelar ou intra-partícula, desidroxilação e calcinação, delaminação e reagregação de argilas minerais esmectíticas e tratamentos físicos como liofilização, ultrasom e plasma [5].

No âmbito dessa abordagem será apresentada uma revisão acerca das argilas organofílicas, incluindo suas características, aplicações, síntese pelas técnicas de troca de 
cátions e interações íon-dipolo, compostos de intercalação e as técnicas de caracterização utilizadas para avaliar propriedades das argilas organofílicas, onde são discutidas várias propriedades.

\section{Argilas organofílicas}

Argilas organofílicas são argilas que contém moléculas orgânicas intercaladas entre as camadas estruturais. As pesquisas de intercalação de moléculas orgânicas em argilas tiveram início na década de 1920, após a introdução da técnica de difração de raios X em 1913 [6]. A intercalação de espécies orgânicas em esmectitas é um modo de se construir conjuntos inorgânico-orgânico com microestruturas únicas que são controladas por interações hospedeiro-hóspede e hóspede-hóspede [7].

A inserção de moléculas orgânicas faz com que ocorra expansão entre os planos d(001) da argila, e muda sua natureza hidrofílica para hidrofóbica ou organofílica e com isso proporciona diversas possibilidades de aplicações para as argilas.

Tipos de argilas utilizadas para obtenção de argilas organofílicas

As argilas mais utilizadas na preparação de argilas organofílicas são as bentonitas. Bentonita é uma terminologia tecnológica aplicada a argilas com granulação muito fina composta essencialmente por minerais do grupo das esmectitas, sendo mais comum a montmorilonita em concentrações que podem variar de 60 a 95\%, a qual advém da argila descoberta no ano de 1898 por Knight em Fort Benton em Wyoming (EUA). É uma argila que adicionalmente pode conter minerais acessórios como: quartzo, cristobalita, feldspato, pirita, carbonatos, clorita, caulinita, mica e ilita.

Montmorilonita (também denominada esmectita) é o nome dado à argila que foi identificada por Knight em 1896 em Montmorillon, uma cidade na região de Poitou na França (argila que possuem alto teor do argilomineral montmorilonita). A montmorilonita é o argilomineral mais abundante entre as esmectitas, cuja fórmula química geral é $\mathrm{M}_{\mathrm{x}}\left(\mathrm{Al}_{4-\mathrm{x}} \mathrm{Mg}_{\mathrm{x}}\right) \mathrm{Si}_{8} \mathrm{O}_{20}(\mathrm{OH})_{4}$. Possui partículas de tamanhos que podem variar de $2 \mu \mathrm{m}$ a $0,1 \mu \mathrm{m}$, com tamanho médio de $\sim 0,5 \mu \mathrm{m}$ e formato de placas ou lâminas. Pertence ao grupo dos filossilicatos 2:1, cujas placas são caracterizadas por estruturas constituídas por duas folhas tetraédricas de sílica com uma folha central octaédrica de alumina, que são unidas entre si por átomos de oxigênio comuns a ambas folhas. As folhas apresentam continuidade nos eixos a e b e geralmente possuem orientação aproximadamente paralela nos planos (001) dos cristais, que lhes confere a estrutura laminada [2, 8-10]. As lamelas da montmorilonita apresentam perfil irregular, são muito finas, tem tendência a se agregarem no processo de secagem e boa capacidade de delaminação quando colocadas em contato com a água. $\mathrm{O}$ diâmetro é de aproximadamente $100 \mathrm{~nm}$, a espessura pode chegar até $1 \mathrm{~nm}$ e as dimensões laterais podem variar de $30 \mathrm{~nm}$ a várias micra, o que resulta em uma elevada razão de aspecto, podendo atingir aproximadamente 1000 [2, $6,11]$. O empilhamento dessas placas é regido por forças polares relativamente fracas e por forças de van der Waals e entre essas placas existem lacunas denominadas galerias ou camadas intermediárias nas quais residem cátions trocáveis como $\mathrm{Na}^{+}, \mathrm{Ca}^{2+}, \mathrm{Li}^{+}$, fixos eletrostaticamente e com a função de compensar cargas negativas geradas por substituições isomórficas que ocorrem no reticulado, como por exemplo, $\mathrm{Al}^{3+}$ por $\mathrm{Mg}^{2+}$ ou $\mathrm{Fe}^{2+}$, ou $\mathrm{Mg}^{2+}$ por $\mathrm{Li}^{+}$. Cerca de $80 \%$ dos cátions trocáveis na montmorilonita estão presentes nas galerias e $20 \%$ se encontram nas superfícies laterais. A Fig. 1 ilustra uma estrutura em camadas da montmorilonita.

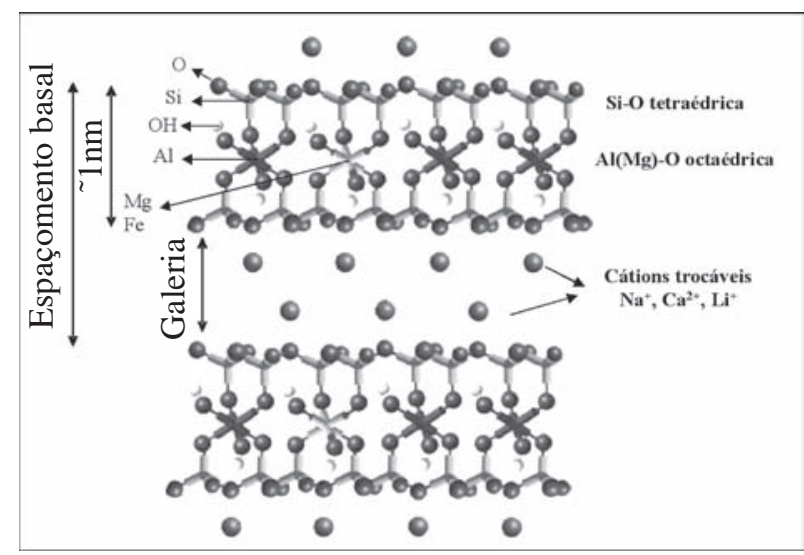

Figura 1: Estrutura da montmorilonita.

[Figure 1: Montmorillonite structure.]

Outras propriedades interessantes da bentonita incluem: moderada carga negativa superficial, elevada capacidade de troca de cátions expressa em meq/100 g que varia de $80 \mathrm{a}$ $150 \mathrm{meq} / 100 \mathrm{~g}$, elevada área específica (área da superfície externa das partículas), em torno de $800 \mathrm{~m}^{2} / \mathrm{g}$, elevada capacidade de inchamento em contato com a água, que pode chegar a 20 vezes o seu volume inicial, propriedades de intercalação de outros componentes entre as camadas e resistência à temperatura e a solventes.

Em resumo, as argilas do grupo esmectita, principalmente a montmorilonita (que compõem a bentonita) são muito utilizadas na preparação das argilas organofílicas devido às pequenas dimensões dos cristais, a elevada capacidade de troca de cátions, e a capacidade de inchamento em água que fazem com que a intercalação de compostos orgânicos utilizados na síntese seja rápida e $100 \%$ completa. No entanto, outras argilas também são utilizadas na síntese de argilas organofílicas, como por exemplo, hectorita [12], fluorohectorita [13], sepiolita [14], micas sintéticas [15-18].

Algumas fluoromicas sintéticas, como fluoro-taeniolita e mica fluoro-tetrasilicica, apresentam capacidade de inchamento em água similar à das esmectitas e com densidade de carga maior. Diferente das argilas naturais, estas argilas sintéticas tem alta cristalinidade, composição controlável e menor quantidade de impurezas, o que torna 
seu uso mais vantajoso que a utilização de argilas naturais, porém existem poucos estudos sobre intercalação química em fluoromicas sintéticas [15].

\section{Aplicações das argilas organofilicas}

Atualmente, a aplicação de destaque das argilas organofílicas está na área de nanocompósitos poliméricos. Entre os nanomateriais utilizados na preparação de nanocompósitos, $70 \%$ do volume utilizado é de argilas organofílicas [19]. A popularização e a eficácia comprovada de bentonitas organofílicas na preparação dos nanocompósitos poliméricos se deve ao fato das bentonitas serem de origem natural e terem baixo custo, a elevada razão de aspecto (relação entre as dimensões da partícula, comprimento versus largura), boacapacidade de delaminação (separação das camadas de argila na matriz polimérica), resistência das partículas a solventes, às temperaturas empregadas em polimerização e às temperaturas e atrito do processo de extrusão.

O procedimento de organofilização da argila é a etapa chave para que ocorra uma dispersão e esfoliação bem sucedida das partículas da argila na matriz polimérica. A natureza organofílica reduz a energia superficial e torna a argila, mais compatível com polímeros orgânicos e o aumento no espaçamento basal facilita a intercalação das cadeias poliméricas entre as camadas da argila. A adição de argilas organofílicas em matrizes poliméricas para preparação de nanocompósitos tem como objetivo a melhoria de propriedades mecânicas, físicas (térmicas e de barreira) e químicas das matrizes poliméricas, além da redução de peso e custo. Tipicamente, as argilas organofílicas substituem cargas convencionais como talco ou fibras de vidro a uma proporção de 3:1. Por exemplo, 5\% de uma argila organofílica pode substituir $15-50 \%$ de uma carga como carbonato de cálcio, melhorando propriedades de impacto e reduzindo custo. [19].

A aplicação de argilas organofílicas em matrizes poliméricas teve inicio na década de 1980 no laboratório de pesquisa da Toyota com o desenvolvimento de nanocompósitos de poliamida contendo 5\% de argila organofílica, que mostraram um aumento de $40 \%$ em resistência a tração, $68 \%$ no módulo de elasticidade, $60 \%$ de resistência à flexão, $126 \%$ no módulo de flexão, enquanto a temperatura de distorção de calor aumentou de 65 para $152^{\circ} \mathrm{C}$ [20]. Argilas organofílicas para nanocompósitos são importadas e tem um custo elevado para o mercado nacional. As principais empresas que produzem argilas organofílicas para nanocompósitos são Southern Clay, Nanocor, SüdChemie e Laviosa, com as respectivas linhas comerciais Cloisite ${ }^{\circledR}$, Nanomer ${ }^{\circledR}$, Nanofil ${ }^{\circledR}$ e Dellite ${ }^{\circledR}$. Não há relatos de empresas nacionais que produzam argilas organofílicas para nanocompósitos.

Argilas organofílicas também podem ser utilizadas como materiais adsorventes pois exibem alta capacidade de remover contaminantes hidrofóbicos de soluções aquosas e por isso são agentes promissores no controle ambiental e na redução de lixiviação, fotodegradação e volatilização de herbicidas, além da alta área especifica que apresentam [21, 22]. Argilas organofílicas são muito utilizadas como adsorventes para remoção de p-nitrofenol e p-clorofenol. Estes compostos fenólicos são largamente usados na industria farmacêutica, petroquímica e outros processos de manufatura química. Devido a efeitos nocivos, efluentes contaminados com compostos fenólicos devem ser tratados antes de serem descartados. Processos secundários de tratamento biológico são comumente empregados para efluentes domésticos e industriais, mas não podem tratar de maneira eficiente efluentes contendo alta concentração de compostos fenólicos [22]. Um considerável aumento na eficiência de adsorção de fenol com o uso de uma montmorilonita modificada com brometo de hexadecil trimetil amônio foi observado [23]. Foi verificada a adsorção de fenol por uma argila organofílica e observado que as interações entre adsorvatoadsorvente (fenol-argila organofílica) são mais favoráveis a altas concentrações de fenol por promover adsorção de mais moléculas [24].

Outras aplicações encontradas são agentes de controle reológico, para preparação de lacas termo-resistentes, no espessamento de tintas, adesivos, em massas de moldagem, em vernizes refratários, produtos farmacêuticos, cosméticos, componentes tixotrópicos em fluidos à base de óleo para perfuração de poços de petróleo, etc [2, 25-27].

\section{Síntese das argilas organofílicas}

A síntese de bentonitas organofílicas ou montmorilonitas propriamente ditas é geralmente feita com a técnica de troca de íons. Essa técnica vem sendo utilizada há cinco décadas [25]. Nesta técnica é feita a modificação superficial da argila bentonita com a substituição de cátions trocáveis presentes nas galerias da argila, geralmente $\mathrm{Na}^{+}$que é mais facilmente trocável por ser monovalente, por cátions orgânicos de sais quaternários de amônio (surfactantes catiônicos) ou mesmo outros tipos de sais, em solução aquosa. A quantidade de intercalante ligado à superfície das lamelas da argila é limitada pela capacidade de troca de cátions da argila. A técnica de troca de íons consiste basicamente em dispersar a argila em água quente, adicionar o sal quaternário de amônio previamente dissolvido e manter em agitação sob determinado período, lavar para retirar o excesso de sal que não reagiu, filtrar, secar e desagregar o material obtido. Um esquema da síntese de argilas organofílicas pela técnica de troca de cátions está ilustrado na Fig. 2. Não existem condições de processamento definidas para preparação das argilas organofílicas. Vários procedimentos de preparação de argilas organofílicas em escala de laboratório são descritos na referência [28].

Foram preparadas misturas de suspensões aquosas de silicatos (esmectita e mica sintética) e sais quaternários de amônio (em concentrações que variaram de 0,25 a 2 vezes a capacidade de troca de cátions das argilas) e a agitaram por $2 \mathrm{~h}$ a $60^{\circ} \mathrm{C}$. Após a etapa de agitação deixaram a mistura em repouso por $24 \mathrm{~h}$ e o procedimento foi repetido. Os produtos 
obtidos foram lavados de 3 a 6 vezes com volumes $500 \mathrm{~mL}$ de água deionizada até a água de lavagem ficar livre dos íons brometo provenientes dos sais quaternários de amônio, e então as argilas foram secas a $100{ }^{\circ} \mathrm{C}$ e moídas [16].

Montmorilonita sódica foi dispersa em $5 \mathrm{~L}$ de água quente usando um homogeneizador. Cloreto de octadecil amônio foi adicionado a dispersão de montmorilonita e a solução foi mantida em agitação vigorosa por 5 min formando um precipitado branco. O precipitado foi coletado por filtração, lavado três vezes a quente para remover o excesso de íons cloreto, e seco [29]. Outras metodologias descritas na literatura que utilizam a técnica de troca de íons podem ser encontradas [13, 26, 30-38], entre outras. As condições de processamento encontradas, como concentração do sal, tempo e velocidade de agitação, temperaturas, são bastante variadas, e isso mostra a necessidade de estudos para definir melhor esses parâmetros.

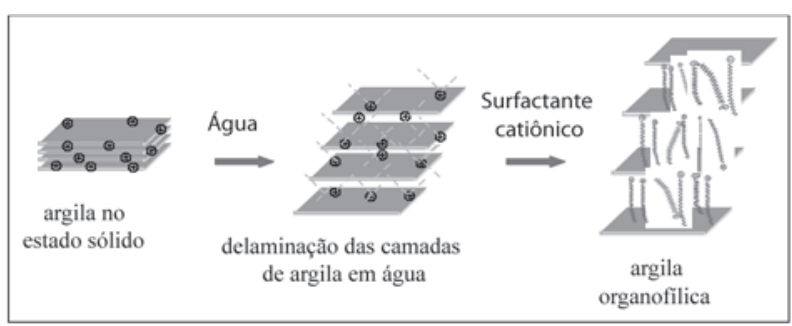

Figura 2: Esquema de troca de cátions em argila.

[Figure 2: Scheme of cation exchange in clay.]

Outra rota utilizada na preparação de argilas organofílicas é a técnica de intercalação íon-dipolo, técnica que começou a ser utilizada pela empresa Nanocor na década de 1990 [6]. Consiste em afixar moléculas orgânicas com grupos polares aos cátions interlamelares (trocáveis) onde as espécies negativas interagem com as cargas positivas dos cátions, formando estruturas em que são presentes regiões rígidas em torno de cada cátion, em um processo em que geralmente não se utiliza água ou outro solvente. A adsorção de moléculas polares também pode ocorrer por pontes de hidrogênio formadas com os átomos de oxigênio das camadas de silicato. A intercalação no estado sólido tem a vantagem de não utilizar grandes quantidades de água para lavar a argila, como no caso da troca de cátions, além de ser mais fácil e adequado para industrialização [6, 25, 39]. Exemplos de síntese de argilas organofílicas pela técnica íon-dípolo são discutidos de maneira resumida a seguir.

Várias composições contendo montmorilonita e octadecilamina em proporções que variam de 1:10 a 1:0,10 massa montmorilonita/massa de octadecilamina foram misturadas a $80{ }^{\circ} \mathrm{C}$ e recozidas na mesma temperatura sob vácuo por $6 \mathrm{~h}$. A intercalação da octadecilamina foi avaliada através da variação do espaçamento basal. O maior espaçamento basal $\mathrm{d}(001)=5,6 \mathrm{~nm}$ foi observado para a amostra com a proporção $1: 10$, enquanto o menor espaçamento basal $\mathrm{d}(001)=1,55 \mathrm{~nm}$ foi obtido para a proporção 1: 0,10 [6].

Os complexos de pirrolidona (metilpirrolidona, octilpirrolidona e dodecilpirrolidona), os álcoois (butanol, hexanol, octanol, decanol, dodecanol, tetradecanol e octadecanol) e também os aldeídos (butanal, hexanal, octanal, decanal e dodecanal) foram intercalados em montmorilonita. No procedimento experimental $250 \mathrm{~g}$ de argila foram misturadas com pequenas quantidades de água, tipicamente $25 \mathrm{~mL}$, para expandir as camadas e então o composto orgânico foi adicionado e misturado. Com os álcoois sólidos à temperatura ambiente foi feito um aquecimento e adicionado metanol para manter o estado líquido durante o processo de intercalação do álcool na argila. As proporções utilizadas em miliequivalentes de composto orgânico para íon sódio foram $1: 1,2: 1$ e $3: 1$. Os produtos obtidos foram moídos várias vezes, secos em ar e moídos novamente e peneirados até se obter tamanho de partícula menor que $75 \mu \mathrm{m}$. Entre os complexos de pirrolidona o maior espaçamento basal, $3,72 \mathrm{~nm}$, medido experimentalmente por difração de raios $\mathrm{X}$, foi encontrado para dodecilpirrolidona na proporção 3:1.

Os álcoois contendo mais de 10 carbonos na cadeia exibiram comportamentos bifásicos. Estas duas fases podem ser atribuídas a uma estrutura onde as moléculas de álcool ficam paralelas à superfície da argila. Para o tetradecanol na proporção de 3:1 foram observados espaçamentos de $1,31 \mathrm{~nm}$, correspondendo ao álcool que fica próximo a superfície, e uma segunda fase com espaçamento de $2,95 \mathrm{~nm}$, correspondendo ao complexo "auto-reunido". Nos aldeídos somente o dodecanal na proporção 3:1 sugeriu a formação de uma estrutura "auto-reunida". Todos os complexos exibiram espaçamentos de 1,34 nm [25].

\section{Estruturas das argilas organofílicas}

Dependendo da densidade de carga da argila e do íon surfactante, diferentes arranjos podem ser obtidos na estrutura da argila organofílica. Os íons de alquilamônio podem ter orientação paralela à superfície das camadas de argila como monocamada ou bicamada, ou dependendo da densidade de empacotamento os íons podem ficar em

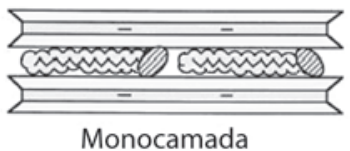

Monocamada

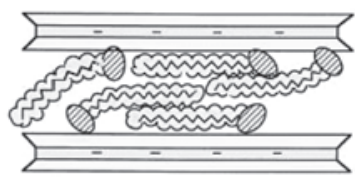

Pseudo-tricamada

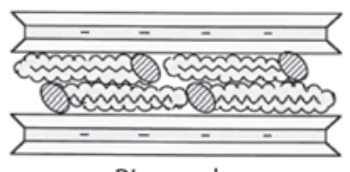

Bicamada

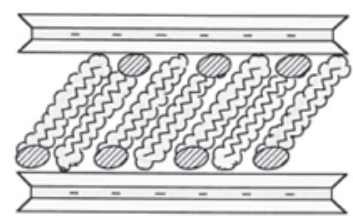

Estrutura tipo parafina
Figura 3: Orientações de íons alquilamônio entre galerias da argila. [Figure 3: Orientations of alkylammonium ions in the galleries of clay.] 


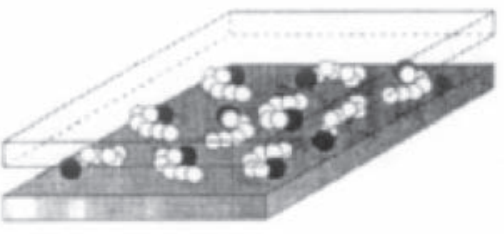

(a)

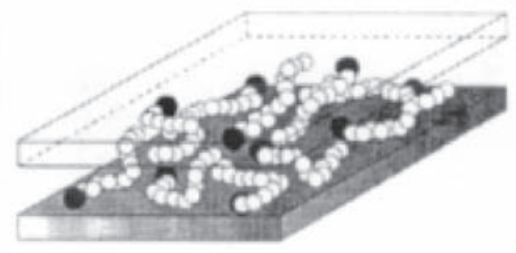

(b)

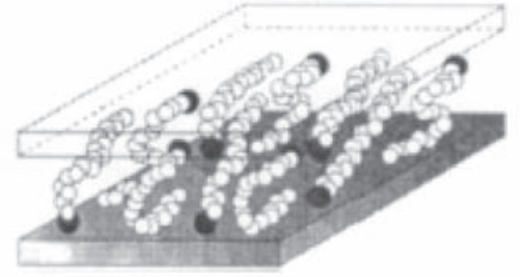

(c)

Figura 4: Modelos de agregação de cadeias alquila [30]: a) cadeias curtas isoladas, monocamada lateral; b) cadeias de comprimento intermediário, desordem no plano e interligação para formar estruturas quase bicamadas; c) cadeias compridas: ordem das camadas intermediárias aumenta levando à formação de um meio tipo líquido cristalino.

[Figure 4: Alkyl chain aggregation models [30]: a) short chain lengths, lateral monolayer; b) medium chain lengths, in-plane disorder and interdigitation to form quasi bilayers; c) long lengths: interlayer order increases leading to a liquid-crystalline polymer environment.]

posições pseudo-tricamada ou ainda, ficar inclinados como estrutura parafínica, podendo ser monocamada ou bicamada, conforme ilustrado na Fig. 3 [11, 40]. As orientações dos íons de alquilamônio em argilas organofílicas foram inicialmente deduzidas por medidas de difração de raios X e infravermelho [40].

No entanto, foi proposto um modelo mais realístico usando experimentos em FTIR associados à difração de raios X para investigar a estrutura interlamelar e o estado das fases de alquilamônio intercaladas entre as camadas de silicato [30]. Monitorando as variações de freqüências de estiramentos assimétricos e deformações angulares do grupo $\mathrm{CH}_{2}$ como função da densidade de empacotamento interlamelar, comprimento da cadeia e temperatura foi verificado que cadeias intercaladas existem em vários graus de ordenação que podem variar de estruturas semelhantes a líquido até sólido. Os principais resultados são resumidos a seguir:

- sob a maioria das condições, uma conformação desordenada (gauche) semelhante a um líquido é predominante sobre a conformação ordenada (trans), que é semelhante a um sólido;

- em geral, quando a densidade de empacotamento ou o comprimento das cadeias diminuem ou a temperatura aumenta, as cadeias intercaladas adotam uma estrutura mais desordenada, semelhante a um líquido, resultando em um aumento na razão da conformação gauche/trans.

Quando a área superficial por molécula está em uma certa faixa, as cadeias não são completamente desordenadas, mas conservam uma certa ordem na orientação similar ao estado líquido cristalino. Uma vez que as cadeias são livres para se mover e se reorientar no estado semelhante a líquido, podem alcançar configurações de equilíbrio muito mais rapidamente comparadas aquelas em estado semelhante a sólido.

A Fig. 4 mostra uma representação esquemática das estruturas intercaladas por cadeias alquílicas de sais quaternários de amônio com diferentes comprimentos [30]. Pode ser observado que com o aumento do número de átomos de carbono, as cadeias adotam estruturas mais ordenadas.

Em 1998 foram utilizados experimentos de modelagem molecular para interpretar as orientações de cadeias nas argilas organofílicas [41]. Simulações de dinâmica molecular foram utilizadas para estudar densidade, força exercida pela moléculas, configuração da cadeia e a razão de conformação trans-gauche. Os resultados encontrados serão discutidos de maneira resumida a seguir. A Fig. 5 mostra as configurações moleculares dos surfactantes intercalados em argilas (sem a presença das camadas de silicato), obtidas durante a execução do programa de modelagem molecular.

(a)

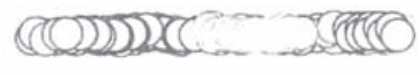

(b)
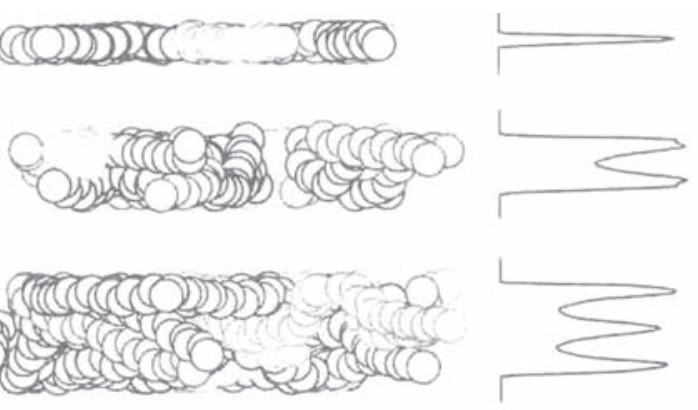

Figura 5: Configurações moleculares de surfactantes com cadeias carbônicas de diferentes tamanhos intercalados em argilas com diferentes capacidades de troca de cátions em modelagem molecular [41]: a) monocamada (C9, CTC $=0,8 \mathrm{meq} / \mathrm{g})$; b) bicamada (C11, $\mathrm{CTC}=1,0 \mathrm{meq} / \mathrm{g}) ; \mathrm{c})$ tricamada $(\mathrm{C} 19, \mathrm{CTC}=1,5 \mathrm{meq} / \mathrm{g})$.

[Figure 5: Modeling molecular of surfactant configurations with different chain lengths intercalated in clays with different cation exchange capacity by [41]: a) monolayer $(C 9, C E C=0.9 \mathrm{meq} / \mathrm{g} ;, b)$ bilayer $(C 11, C E C=1.0 \mathrm{meq} / \mathrm{g}) ; \mathrm{c})$ trilayer $(C 19, C E C=1.5 \mathrm{meq} / \mathrm{g})$.]

A configuração mais estável é a do tipo monocamada com espaçamento basal 1,32 $\mathrm{nm}$. O tipo bicamada corresponde a um espaçamento basal de $1,80 \mathrm{~nm}$ e o tricamada 2,27 nm. As configurações obtidas na Fig. 5 revelaram arranjos desordenados semelhantes aos líquidos e que as cadeias orgânicas não permanecem planas à superfície das camadas, mas se sobrepõem com outros íons em camadas opostas entre as galerias. Para configurações bicamadas, quase metade dos grupos $\mathrm{CH}_{2}$ podem ser encontrados em camadas opostas ao grupo amônio graftizado na cadeia, enquanto nos arranjos tricamada os grupos $\mathrm{CH}_{2}$ provavelmente "pulam" 
para o meio da camada, mas relativamente poucos serão encontrados em camadas opostas ao grupo positivo.

Outro aspecto é a questão da pressão entre as galerias, que aumenta acima da pressão ambiente quando o comprimento da cadeia aumenta e o espaçamento basal e a capacidade de troca de cátions permanecem constantes. Como o sistema não pode sustentar altas pressões, as cadeias são reunidas em novas camadas forçando a expansão das galerias. $\mathrm{O}$ aumento ocorrido nos espaçamentos basais é regido pelo comprimento da cadeia e pela capacidade de troca de cátions. $\mathrm{O}$ espaçamento basal aumenta mais rapidamente com o comprimento da cadeia em silicatos com alta capacidade de troca de cátions, além disso, o espaçamento basal será mais largo para elevadas capacidades de troca de cátions.

Quando a densidade do sistema aumenta, assim como o comprimento da cadeia, há um espaçamento basal constante, os sistemas que são mais densos irão formar estruturas com mínimo desvio do espaçamento basal da espessura de monocamada ou bicamada. Os sistemas sobrecarregados formam estruturas com larga distribuição de altura de galerias, dando picos de difração muito largos, embora os mais prováveis espaçamentos basais estão muito próximos àqueles de monocamada e bicamada. A porcentagem de conformação trans aumenta severamente quando se aproxima do comprimento máximo da cadeia antes do sistema "pular" de uma estrutura monocamada para bicamada, pois neste ponto as moléculas de surfactante favorecem uma conformação totalmente trans para obter um empacotamento mais eficiente e acomodar o alto número de grupos $\mathrm{CH}_{2}$ e $\mathrm{CH}_{3}$ entre uma galeria monocamada.

\section{Compostos orgânicos para preparação de argilas organofílicas}

Os compostos orgânicos mais utilizados na preparação de argilas organofílicas são os sais quaternários de amônio de cadeias longas. Esses sais representam o estado final na aquilação do nitrogênio de aminas, onde quatro grupos orgânicos se encontram covalentemente ligados ao átomo de nitrogênio e, a carga positiva deste átomo é neutralizada por um anion, geralmente um halogênio, conforme ilustrado na Fig. 6 [42].

$$
\begin{array}{|l|}
\hline \mathrm{R} \\
\mathrm{R}: \stackrel{\mathrm{N}}{\mathrm{R}} \mathrm{R}+\mathrm{X}^{-} \\
\mathrm{R}
\end{array}
$$

Figura 6: Fórmula estrutural do sal quaternário de amônio, R = radical orgânico, $\mathrm{X}^{-}=$halogênio.

[Figure 6: Structural formula of ammonium quaternary salt, $R=$ organic radical, $X^{-}=$halogen.]

Os sais quaternários de amônio são produzidos a partir de aminas de cadeia longa que por sua vez são produzidas industrialmente a partir de ácidos graxos que são misturas de ácidos com cadeias alquílicas de diferentes comprimentos, extraídos de óleos e gorduras naturais como tallow (sebo), coco e dendê.

Atualmente, existe uma vasta literatura que relata modificação de argilas com diversos tipos de sais quaternários de amônio, em escala de laboratório. Os tipos de sais quaternários de amônio, que geralmente estão na forma de cloreto ou brometo, comumente usados na preparação de argilas organofílicas estão listados na Tabela I.

Tabela I - Tipos de sais quaternários de amônio usados para preparação de argilas organofílicas.

[Table I - Kinds of ammonium quaternary salts used to prepare organophilic clays.]

\begin{tabular}{ll}
\hline \multicolumn{1}{c}{ Sal quaternário } & \multicolumn{1}{c}{ Fórmula química } \\
\hline $\begin{array}{l}\text { Haleto de diestearil } \\
\text { dimetil amônio }\end{array}$ & {$\left[\left(\mathrm{CH}_{3}\right)_{2}\left(\mathrm{C}_{18} \mathrm{H}_{37}\right)_{2} \mathrm{~N}^{+}\right] \mathrm{X}^{-}$} \\
$\begin{array}{l}\text { Haleto de dialquil dimetil } \\
\text { amônio }\end{array}$ & {$\left[\left(\mathrm{CH}_{3}\right)_{2} \mathrm{R}_{2} \mathrm{~N}^{+}\right] \mathrm{X}^{-}$} \\
$\begin{array}{l}\text { Haleto de alquil benzil } \\
\text { dimetil amônio }\end{array}$ & {$\left[\left(\mathrm{CH}_{3}\right)_{2}\left(\mathrm{CH}_{2} \mathrm{C}_{6} \mathrm{H}_{5}\right) \mathrm{RN}^{+}\right] \mathrm{X}^{-}$} \\
$\begin{array}{l}\text { Haleto de alquil dimetil } \\
\text { hidroxietil amônio }\end{array}$ & {$\left[\left(\mathrm{CH}_{3}\right)_{2}\left(\mathrm{C}_{18} \mathrm{H}_{37}\right)\left(\mathrm{C}_{2} \mathrm{H}_{4} \mathrm{OH}\right) \mathrm{N}^{+}\right] \mathrm{X}^{-}$} \\
$\begin{array}{l}\text { Haleto de alquil trimetil } \\
\text { amônio }\end{array}$ & {$\left[\left(\mathrm{CH}_{3}\right)_{3} \mathrm{RN}^{+}\right] \mathrm{X}^{-}$} \\
$\begin{array}{l}\text { Haleto de cetil trimetil } \\
\text { amônio }\end{array}$ & $\left(\mathrm{C}_{12} \mathrm{H}_{33} \mathrm{~N}^{+}\left(\mathrm{CH}_{3}\right)_{3} \mathrm{X}^{-}\right.$ \\
\hline
\end{tabular}

No caso das argilas organofílicas comerciais para nanocompósitos poliméricos observa-se que o tipo de sal empregado na modificação da argila tem influencia na afinidade com o tipo de polímero em função da polaridade do mesmo, ou seja, polímeros mais polares requerem argilas mais polares enquanto para polímeros apolares argilas menor polaridade são mais adequadas. Para polímeros apolares como polipropileno e polietileno as argilas são geralmente modificadas com haletos de diestearil dimetil amônio enquanto para polímeros polares como a poliamida, poli(tereftalato de etileno), as argilas são modificadas com haletos de alquil benzil dimetil amônio ou haletos de alquil dimetil hidroxietil amônio. Para as argilas organofílicas empregadas como material adsorvente, as que são modificadas com sais contendo grupos benzílicos favorecem a adsorção de poluentes aromáticos como benzeno, tolueno, fenol, e seus derivados clorados e também herbididas [23]. Além disso, diferentes tipos de sais, em função dos diferentes comprimentos das cadeias alquílicas produzem argilas organofílicas com espaçamentos basais variados. As argilas também podem ser modificadas com sais quaternários de amônio e co-intercaladas com outros tipos de compostos. Alguns exemplos com base na literatura recente desses tipos de intercalação e as variações proporcionadas nos espaçamentos basais das argilas são 
discutidos resumidamente a seguir.

Foi preparada uma argila montmorilonita organofílica com o sal brometo de hexadecil trimetil amônio que apresentou um espaçamento basal de 1,96 nm, enquanto a forma na forma sódica o espaçamento basal era 1,24 nm, caracterizando a obtenção da argila organofílica. Essa argila foi co-intercalada com epóxi propil metacrilato e atingiu um espaçamento basal 2,98 nm [43]. Uma série homologa de sais quaternários de amônio foi utilizada na preparação de argilas montmorilonitas organofílicas. Os sais da série homologa são derivados de brometo de alquil dimetil benzil amônio, onde os radicais alquil são metil, butil, hexil, octil, decil e dodecil. Os seguintes sais foram utilizados: brometo de benzil trimetil amônio, brometo de butil dimetil benzil amônio, brometo de hexil dimetil benzil amônio, brometo monoidrato de octil dimetil benzil amônio, brometo monoidrato de decil dimetil benzil amônio e brometo de dodecil dimetil amônio [21]. O espaçamento basal da montmorilonita sódica foi $1,2397 \mathrm{~nm}$. Para as argilas intercaladas com brometo de benzil trimetil amônio e brometo de butil dimetil amônio os espaçamentos basais foram $1,4492 \mathrm{~nm}$ e $1,4664 \mathrm{~nm}$, respectivamente, enquanto com o brometo de dodecil trimetil amônio foi observado um espaçamento basal $1,7969 \mathrm{~nm}$. Os resultados sugerem que com a série homologa de cadeias curtas os cátions amônio ficam paralelos à superfície das camadas de argila, mas para a série homologa de cadeias longas é formado um sistema interligado de cadeias alquílicas [21].

Uma bentonita sódica foi organofilizada com os sais quaternários de amônio brometo de tetradecil trimetil amônio e brometo de hexadecil trimetil amônio em quantidades equivalentes a $25 \%, 50 \%$ e $100 \%$ da capacidade de troca de cátions da argila [22]. A bentonita apresentou um espaçamento basal inicial 1,195 nm, e após a modificação com o brometo de tetradecil trimetil amônio os espaçamentos basais passaram a ser $1,36 \mathrm{~nm}, 1,426 \mathrm{~nm}$ e $1,841 \mathrm{~nm}$, e com o brometo de hexadecil trimetil amônio os espaçamentos basais foram 1,403 nm, 1,578 nm e 1,803 nm, para as respectivas concentrações de $25 \%, 50 \%$ e $100 \%$ da capacidade de troca de cátions. Os valores dos espaçamentos basais observados para as amostras modificadas com ambos os sais em concentrações equivalentes a $100 \%$ da capacidade de troca de cátions da argila apontaram que um arranjo estrutural do tipo bicamada foi formado. Para a amostra preparada com o brometo de tetradecil trimetil amônio a concentração de $25 \%$ o arranjo estrutural formado foi do tipo monocamada, enquanto que nas demais amostras apresentaram interestratificação aleatória de estruturas mono e bicamada [22].

Além dos sais quaternários de amônio, outros compostos orgânicos também são utilizados para modificar argilas. Dentre esses compostos estão os surfactantes nãoiônicos [44], éteres coronários [45], criptantes [45], 2aminopirimidina [14], sais derivados de imidazole [46], álcoois [25], aldeídos [25], n-alquil pirrolidonas [25], anidrido maleico [29, 47], pentaeritritol [48], sais de fosfonio, silanos [49] e também os sais de anilina [39]. Para estes compostos são encontradas publicações isoladas, o que não reflete o mesmo grau de avanço da modificação das argilas atingido com os sais quaternários de amônio, mas ilustra o potencial a ser explorado na modificação de argilas com diferentes tipos de compostos orgânicos.

\section{TÉCNICAS UTILIZADAS NA CARACTERIZAÇÃO DE ARGILAS ORGANOFÍLICAS}

\section{Caracterização estrutural}

\section{Difração de raios $X$}

A difração de raios $\mathrm{X}$ é a técnica mais utilizada para caracterizar híbridos de surfactante e argila. A técnica permitir avaliar a obtenção de uma argila organofílica através da comparação da medida dos espaçamentos basais $d(001)$, da argila não modificada com a argila modificada quimicamente. Na montmorilonita sódica (natural ou ativada), o $d(001)$ está em torno de 1,2 a 1,4 nm. Quando uma molécula orgânica é intercalada entre as galerias das camadas de argila para formar uma argila organofílica a medida do espaçamento basal aumenta. $\mathrm{O}$ valor do espaçamento basal adquirido varia de acordo com o tipo, concentração e orientação do surfactante empregado e metodologia de preparação. Alguns exemplos de variações nos espaçamentos basais e estruturas formadas com diferentes compostos orgânicos foram discutidos na seção de compostos de intercalação. Em difratogramas de raios $\mathrm{X}$ de argilas organofílicas podem aparecer múltiplos picos, que podem ser tanto de interferência ou da indicação da existência de várias populações com diferentes distâncias nos planos basais. Outra consideração é feita sobre água adsorvida entre as galerias de argilas parcialmente organofílicas, o que também proporciona separação das camadas e o aparecimento de novos picos [50].

Foram preparadas montmorilonitas organofílicas com o sal cloreto de n-cetil piridínio em concentrações correspondentes a $10,30,50,70$ e $100 \%$ a capacidade de troca de cátions teórica da argila [50]. A Fig. 7 mostra os difratogramas da montmorilonita não modificada e das montmorilonitas organofílicas e os valores dos espaçamentos basais estão na Tabela II. Os resultados mostram que populações com diferentes espaçamentos basais são observadas para as diferentes quantidades de sal intercalado, e os espaçamentos basais aumentam com o aumento da concentração do sal. Para as composições modificadas com 30 e $50 \%$ da capacidade de troca de cátions foram observadas duas populações de espaçamentos basais, enquanto nas demais composições há apenas uma população. As amostras foram secas a vácuo a $80{ }^{\circ} \mathrm{C}$ e os picos referentes a $1,73 \mathrm{~nm}$ da composição modificada a $30 \%$ e $1,70 \mathrm{~nm}$ da composição modificada a 50\% desapareceram, sugerindo havia água adsorvida que proporcionou separação entre as galerias da argila dando um pico adicional.

A técnica de difração de raios $\mathrm{X}$ foi utilizada para avaliar estrutura de montmorilonitas organofílicas em função da variação da concentração do surfactante. O surfactante 


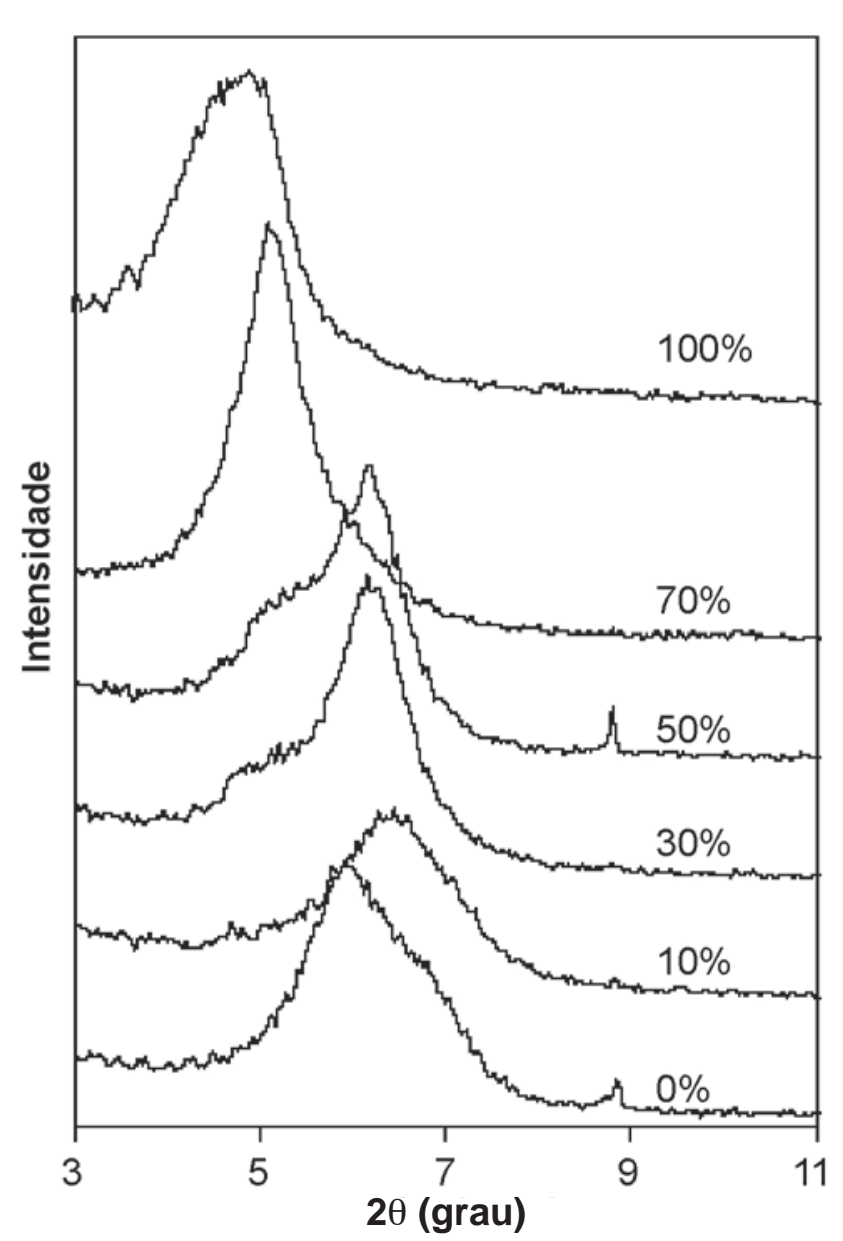

Figura 7: Difratogramas de raios X da montmorilonita modificada com várias concentrações de cloreto de dodecil piridínio correspondentes à capacidade de troca de cátions teórica da argila [50].

[Figure 7: X-ray diffraction patterns of modified montmorillonite with several concentration of piridinium dodecyl chloride related to the theoretical cation exchange capacity of the clay[50].]

Tabela II - Espaçamentos basais obtidos na modificação de montmorilonita com várias concentrações de cloreto de dodecil piridínio correspondentes à capacidade de troca de cátions teórica da argila [50].

[Table II - Basal spacings observed for modified montmorillonite with several concentration of piridinium dodecyl chloride related to the theoretical cation exchange capacity of the clay [50].]

\begin{tabular}{cc}
\hline $\begin{array}{c}\text { Concentração de sal } \\
\text { em função da CTC }(\%)\end{array}$ & $d(\mathrm{~nm})$ \\
\hline 0 & 1,26 \\
10 & 1,38 \\
30 & 1,43 e 1,73 \\
50 & 1,43 e 1,70 \\
70 & 1,73 \\
100 & 1,77 \\
\hline
\end{tabular}

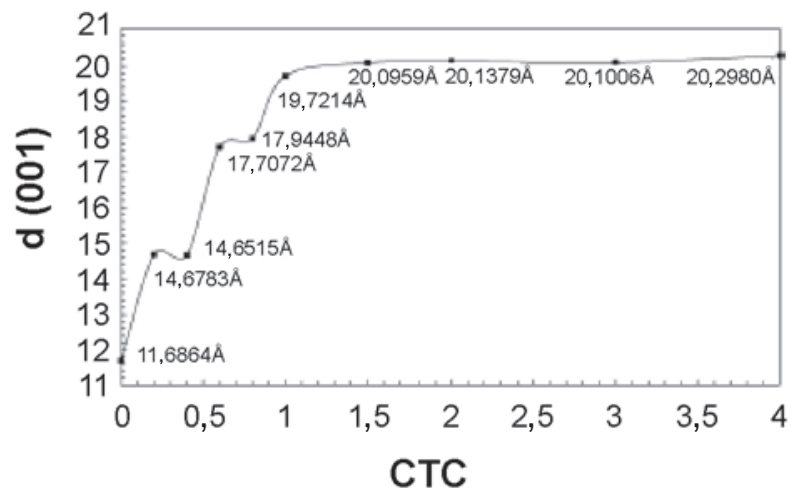

Figura 8: Espaçamentos basais versus concentraçȧo do surfactante [37].

[Figure 8: Basal spacings versus surfactant concentration [37.]

utilizado na preparação das argilas foi o brometo de octadecil trimetil amônio em concentrações equivalentes a 0,2, 0,4, 0,6, 0,8, 1,0, 1,5, 2,0, 3,0 e 4,0 vezes a capacidade de troca de cátions da argila. A Fig. 8 mostra um gráfico dos espaçamentos basais versus a concentração do surfactante [37].

O gráfico mostra um espaçamento basal de 11,69 para a montmorilonita na forma sódica e esse espaçamento aumenta em função da concentração do surfactante. Para a concentração 0,2, o espaçamento basal é ligeiramente maior que para 0,4. Esse comportamento é atribuído ao fato de que na concentração 0,2 ainda há uma grande quantidade de cátions sódio trocáveis que podem adsorver água devido a alta energia de hidratação, o que torna o espaçamento basal da concentração 0,2 maior que o espaçamento da concentração de 0,4 . O valores dos espaçamentos basais nas respectivas concentrações 0,2 e 0,4 indicam que os cátions octadecil trimetil amônio formaram um arranjo estrutural do tipo monocamada lateral entre as galerias da argila [37]. Nas concentrações 0,6 e 0,8 os valores dos espaçamentos basais foram 17,71 e $17,94 \AA$, respectivamente, o que reflete a formação de um arranjo do tipo bicamada lateral, enquanto na concentração 1,0 o espaçamento basal é de $19,72 \AA$ e o tipo de arranjo estrutural do surfactante que foi formado está entre bicamada lateral e pseudo-tricamada [37]. Com a concentração 1,5 o espaçamento basal alcança um platô de 20,1 $\AA$. De 1,5 para 4,0 o espaçamento basal aumenta ligeiramente e o valor máximo é de 20,3 ̊̊ para a concentração 4,0. O tipo de arranjo estrutural nessas concentrações é do tipo pseudo-tricamada [37].

\section{FTIR}

A técnica de FTIR também é muito útil no estudo de argilas organofílicas. Fornece informações detalhadas sobre a estrutura interlamelar e a fase de alquilamônio entre as galerias da argila. Os resultados revelam as variações de freqüência nos estiramentos e deformações angulares de grupos $\mathrm{CH}_{2}$ dos sais orgânicos como função da densidade de empacotamento, comprimento da cadeia e temperatura. A intercalação de cátions octadecil amônio em montmorilonita 
foi avaliada através da comparação dos espectros de FT-IR da montmorilonita sódica e da montmorilonita modificada quimicamente. Nos espectros da argila organofílica foi observado o aparecimento de bandas de absorção nas regiões de $2921 \mathrm{~cm}^{-1}$ e $2851 \mathrm{~cm}^{-1}$ que correspondem aos estiramentos assimétricos e simétricos das ligações $\mathrm{C}-\mathrm{H}$ (dos grupos $\mathrm{CH}_{3}$ e $\mathrm{CH}_{2}$ ). Também foram observados bandas nas regiões de $1469 \mathrm{~cm}^{-1}$ e $3253 \mathrm{~cm}^{-1}$ que correspondem a deformações angulares do grupo metileno e estiramentos da ligação N-H, respectivamente, indicando que os cátions de amônio foram intercalados entre as galerias da montmorilonita [51].

Também foram observadas fortes bandas de absorção nas regiões de 2984, 2955 e $2897 \mathrm{~cm}^{-1}$, referentes aos grupos $\mathrm{CH}_{3}$ e $\mathrm{CH}_{2}$ em uma bentonita intercalada cátions tetraetilamônio [22]. Nas regiões de 1495 e $1393 \mathrm{~cm}^{-1}$ também foram encontradas fortes bandas de absorção que são atribuídas ao íon amônio. No trabalho [35] onde foram feitas modificações em montmorilonita com a série de sais do grupo cloreto de (alquil oximetil) dodecil dimetil amônio, a intercalação dos sais nas galerias da montmorilonita foi confirmada independentemente por FT-IR. Nos espectros das argilas modificadas ocorreu o aparecimento de bandas correspondentes a estiramentos do grupo $\mathrm{C}-\mathrm{C}$ na região de $1468 \mathrm{~cm}^{-1}$ e vibrações assimétricas e simétricas do grupo $\mathrm{C}-\mathrm{H}$ nas regiões entre 2930 e $2856 \mathrm{~cm}^{-1}$. Além disso, foi feita uma comparação entre os espectros da montmorilonita não modificada com os espectros das modificadas. A montmorilonita não modificada foi caracterizada por bandas de estiramentos e deformações angulares do grupo Si-O e

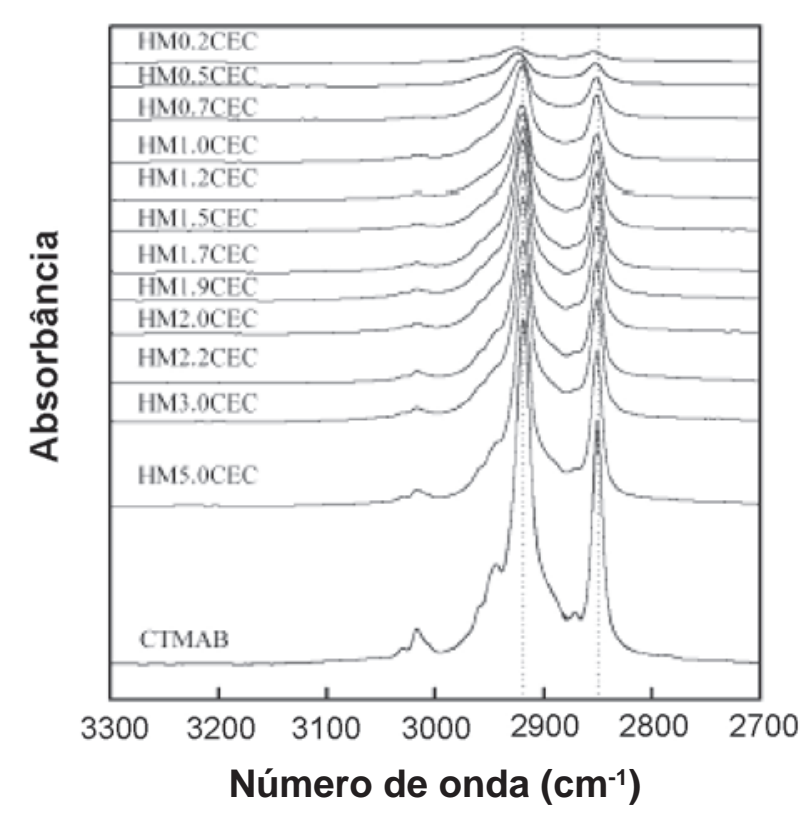

Figura 9: Espectros de FTIR para brometo de cetil trimetil amônio e montmorilonita intercalada com brometo de cetil trimetil amônio, na região de 3300-2700 $\mathrm{cm}^{-1}$ [38].

[Figure 9: FTIR spectra of cetyl trimethyl ammonium bromide and montmorillonite intercalated with the salt, region of 3330$2700 \mathrm{~cm}^{-1}$ [38].] bandas de deformações angulares de $\mathrm{OH}$, que são típicas do material em regiões abaixo de $1200 \mathrm{~cm}^{-1}$. Nenhuma variação significativa foi observada entre os espectros das formas não modificada e modificadas com relação à banda característica da montmorilonita que aparece na região de $1030 \mathrm{~cm}^{-1}$, banda de estiramento Si-O, que ficou entre 1030 e $1027 \mathrm{~cm}^{-1}$ nas amostras modificadas organicamente [35].

A técnica de FT-IR foi utilizada para avaliar a intercalação de cátions do sal brometo de cetil trimetil amônio em montmorilonita sódica. As concentrações do sal variaram de 0,2 a 5,0 vezes a capacidade de troca de cátions da argila [38]. Nos espectros de FT-IR foram observadas bandas nas regiões de $\sim 2920$ e $2850 \mathrm{~cm}^{-1}$, conforme ilustrado na Fig. 9 , que correspondem aos estiramentos assimétricos $\left(v_{\mathrm{as}}\right)$ e simétricos $\left(v_{\mathrm{s}}\right)$ dos grupos $\mathrm{CH}_{2}$ dos sais orgânicos.

$\mathrm{O}$ aumento da concentração sal de 0,2 para 5,0 vezes a capacidade de troca de cátions da argila e a densidade de empacotamento entre as galerias da argila, fez com que as bandas de $v_{\text {s }}$ variassem de 2926 para $2916 \mathrm{~cm}^{-1}$ e as de $v_{\text {s }}$ 2854 para $2850 \mathrm{~cm}^{-1}$. A variação das bandas de baixa para alta freqüência significa que a conformação altamente ordenada (trans) é reduzida, considerando que a conformação gauche aumente. Isto reflete que, com o aumento da densidade de empacotamento do surfactante, a estrutura molecular de surfactante intercalado semelhante a um líquido muda para uma estrutura tipo sólido [38]. As deformações angulares simétricas e assimétricas dos grupos $\mathrm{CH}_{2}$ são observadas nas regiões entre $1480-1450 \mathrm{~cm}^{-1} \mathrm{e} 740-710 \mathrm{~cm}^{-1}$, respectivamente, conforme ilustrado nas Figs. 10a e 10b.

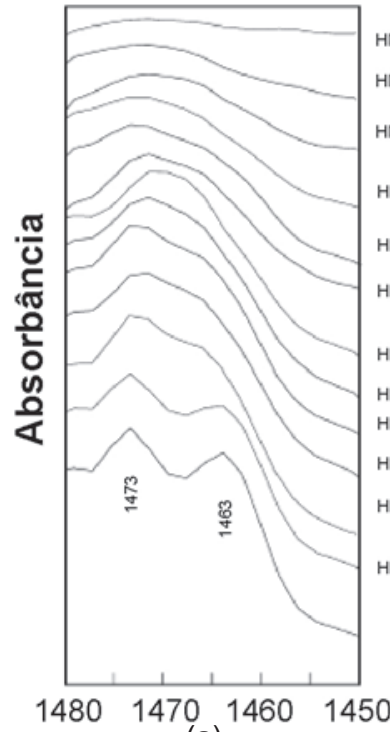

(a)

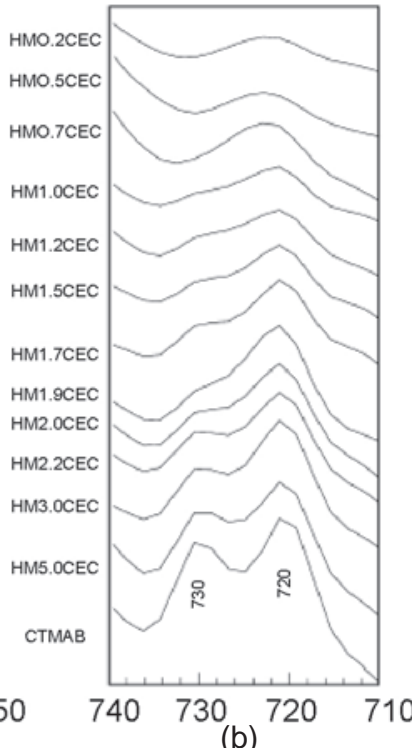

(b)
Número de onda $\left(\mathrm{cm}^{-1}\right)$

Figura 10: Espectros de FTIR nas regiões de deformações angulares do $\mathrm{CH}_{2}(\mathrm{C}-\mathrm{H})$ para híbridos de montmorilonita-brometo de cetil trimetil amônio, a várias concentrações do surfactante: a) 1480$1450 \mathrm{~cm}^{-1}$; b) $740-710 \mathrm{~cm}^{-1}[38]$.

[Figure 10: FTIR spectra in $\mathrm{CH}_{2}(\mathrm{C}-\mathrm{H})$ stretching of cetyl trimethyl ammonium bromide-montmorillonite hybrids recorded at different surfactant concentrations: a) 1480-1450 cm-1; b) 740-710 cm-1 [38].] 
As bandas encontradas nessas regiões diagnosticam o empacotamento de arranjos de cadeias alquílicas reunidas. Os espectros apresentam singletes a 1470 e $720 \mathrm{~cm}^{-1}$, com largura de faixa de $10 \mathrm{~cm}^{-1}$ para as concentrações de 0,2 a 1,0 vez a CTC da argila. Estes largos singletes relatam a existência de uma estrutura molecular do tipo líquido ou empacotamento hexagonal desordenado, onde as cadeias alquílicas rotacionam livremente em torno de seus eixos. Com o aumento da concentração de surfactante e da densidade de empacotamento pode ser observado que os singletes se dividem em duas bandas, o que deve ser atribuído à interação entre os grupos $\mathrm{CH}_{2}$ adjacentes de cadeias vizinhas em um arranjo ortorrômbico de cadeias alquílicas, indicando a variação no meio local do surfactante [38].

\section{Microscopia eletrônica de varredura}

A microscopia eletrônica de varredura é uma técnica que permite avaliar a morfologia das partículas da argila. Diferenças morfológicas entre esmectitas sódica e intercalada com brometo de hexadecil trimetil amônio em concentração equivalente a duas vezes e meia a capacidade de troca de cátions da argila foram avaliadas por microscopia eletrônica de varredura. Nas amostras com a forma sódica foram observados agregados e regiões compactas, enquanto a forma
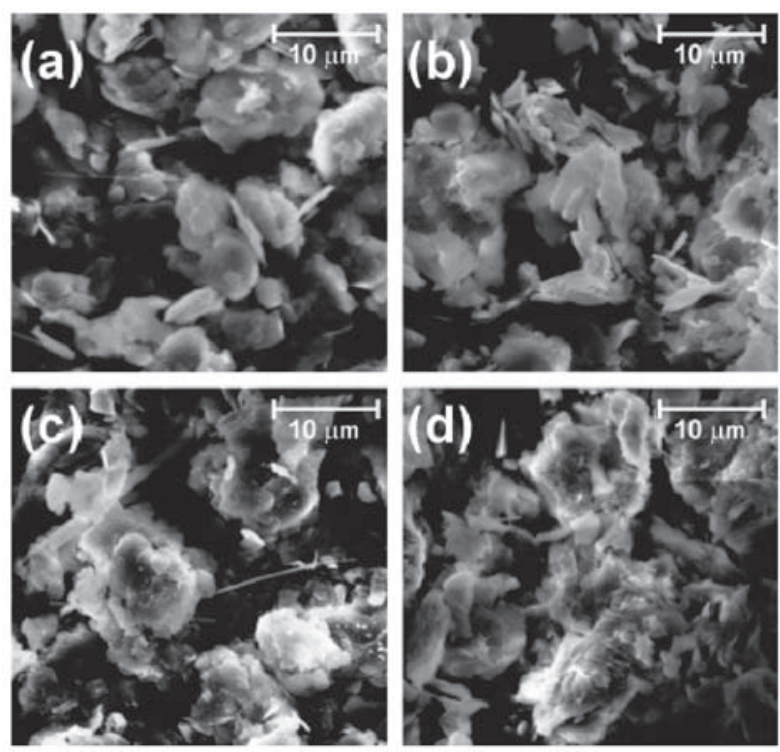

Figura 11: Micrografias obtidas por microscopia eletrônica de varredura: a) montmorilonita sódica; b) montmorilonita modificada com cloreto de (butoximetil) dodecil dimetil amônio; c) montmorilonita modificada com cloreto de dodecil dimetil (dodecil oximetil) amônio e d) montmorilonita modificada com cloreto de (benzil oximetil) dodecil dimetil amônio [35].

[Figure 11: SEM micrographs of: a) sodium montmorillonite; b) montmorillonite modified with modified with (butoxymethyl) dodecyl dimethyl ammonium chloride; $c$ ) montmorillonite modified with (decyloxymethyl) dodecyl dimethyl ammonium chloride and d) montmorillonite modified with (benzyloxymethyl) dodecyl dimethyl ammonium chloride [35].] organofílica apresentou morfologia moderadamente nãoagregada, com aspecto de "cachos" e "cantos dobrados" [52]. As micrografias obtidas em [35], Fig. 11, ilustram um bom exemplo da avaliação da morfologia de uma montmorilonita sódica e de montmorilonitas organofílicas modificadas com cloreto de (butoximetil) dodecil dimetil amônio, cloreto de dodecil dimetil (dodecil oximetil) amônio e cloreto de (benzil oximetil) dodecil dimetil amônio. Foi observado que o processo de intercalação não causou substanciais variações na morfologia das partículas de montmorilonita, porém aumentou a tendência à formação de aglomerados. Na montmorilonita não modificada foi observada uma boa equalização e separação das partículas, irregularidade no formato das partículas e tamanho médio que não excedeu a 3,5 $\mu \mathrm{m}$. Nas montmorilonitas organofílicas as partículas formaram largos aglomerados e o tamanho médio desses aglomerados variou de 7-10 $\mu \mathrm{m}$ para a montmorilonita modificada com cloreto de (butoximetil) dodecil dimetil amônio enquanto na montmorilonita modificada com cloreto de (benzil oximetil) dodecil dimetil amônio o tamanho dos aglomerados foi de 8-15 $\mu \mathrm{m}$ [35].

Brometo de hexadecil trimetil amônio foi intercalado em uma montmorilonita sódica de Wyoming e em uma montmorilonita cálcica do Arizona. As micrografias da montmorilonita de Wyoming organofílica revelaram que as camadas da montmorilonita sódica interagiram com o sal formando uma estrutura com aspecto de "flocos de milho". Com a montmorilonita do Arizona um aspecto diferente foi formado, e a micrografia revelou uma estrutura com camadas ou partículas bastante agregadas [53].

\section{Microscopia eletrônica de transmissão}

A microscopia eletrônica de transmissão permite a observação direta das características estruturais formadas durante a transformação de argilas em argilas organofílicas. Uma avaliação microestrutural foi realizada através de microscopia eletrônica de transmissão de alta resolução de uma argila esmectita organofílica intercalada com brometo de hexadecil trimetil amônio em concentrações equivalentes a 1,0 e 2,5 vezes a capacidade de troca de cátions da argila. As amostras da argila utilizadas para análise foram primeiramente embutidas em resina epóxi e depois cortadas com ultramicrótomo em sessões ultrafinas com espessuras $50-70 \mathrm{~nm}$ [52]. A argila intercalada com o sal na concentração de $1 \mathrm{x}$ a capacidade de troca de cátions mostrou espaçamentos basais 20-24 ̊̊ que são similares aos resultados obtidos por difração de raios $\mathrm{X}$, o que confirma a intercalação dos cátions orgânicos e indica que as cadeias alquílicas são incorporadas como camada pseudo-tricamada. Além disso, observaram que a eqüidistância dos espaçamentos em camadas individuais é prevalecente, porém várias camadas também são deformadas. A micrografia obtida para a argila intercalada com o hexadecil trimetil amônio na concentração de 1,0 vez a CTC está na Fig. 12 [52].

As micrografias das amostras tratadas com concentração de sal 2,5x mostraram que a expansão que ocorre entre as 


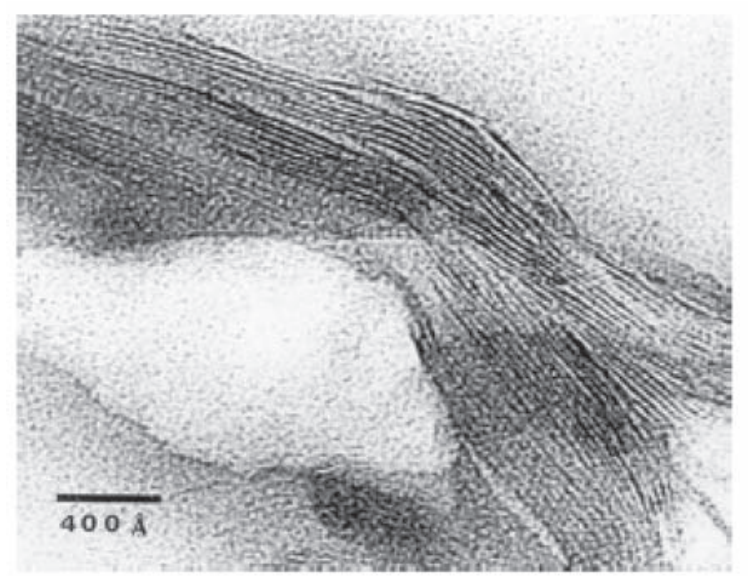

Figura 12: Micrografia obtida por microscopia eletrônica de transmissão da esmectita intercalada com cations hexadecyl trimethyl amônio na concentração de 1x a CTC [52].

[Figure 12: TEM micrograph of smectite intercalated with hexadecyl trimethyl ammonium corresponding to $1 x$ the CEC [52].]

camadas da argila é variável e inconsistente. Muitas camadas da esmectita intercalada com o brometo de hexadecil trimetil amônio mostraram espaçamentos basais de 30-36 ̊, que são um pouco menores que o valor encontrado por difração de raios $\mathrm{X}, 39,4 \AA$, mas há também camadas que atingiram espaçamentos basais maiores que $40 \AA$ chegando até $70 \AA$, conforme pode ser observado nas micrografias apresentadas nas Figs. 13a e 13b; no entanto, é possível que a estabilidade das camadas com espaçamentos acima de $40 \AA$ seja menor. Variando as concentrações do sal os autores observaram que a dispersão das camadas da argila depende fortemente da quantidade de moléculas de surfactante intercaladas entre as galerias. Outras características interessantes também podem ser vistas nas Figs. 13a e 13b. Na Fig. 13a há muitas camadas que são aleatoriamente expandidas ou esfoliadas e camadas regulares que são degeneradas ou destruídas, enquanto na Fig. 13b é possível observar que o inchamento da esmectita contém subparalelismo ou terminação das camadas [52].

A microscopia eletrônica de transmissão também foi empregada para avaliar a intercalação de brometo de hexadecil trimetil amônio em uma montmorilonita sódica de Wyoming e em uma montmorilonita cálcica do Arizona. Para a montmorilonita de Wyoming organofílica a micrografia revelou camadas de argila adjacentes paralelas ou subparalelas com aspecto de "franja ondulada" e a expansão das camadas foi uniforme com espaçamento de $1,8 \mathrm{~nm}$ e entre algumas camadas de $1,5 \mathrm{~nm}$. Com a montmorilonita do Arizona um comportamento diferente foi observado. A argila organofílica apresentou descontinuidade e irregularidade entre as camadas ao longo dos planos e estrutura mais agregada. Foi observado que alguma intercalação ocorreu quando o sal foi adicionado, mas a montmorilonita do Arizona não responde suficientemente a adsorção do surfactante, pois algumas camadas não apresentaram expansão após a adição do sal [53]. Através das diferenças estruturais os resultados mostram que a
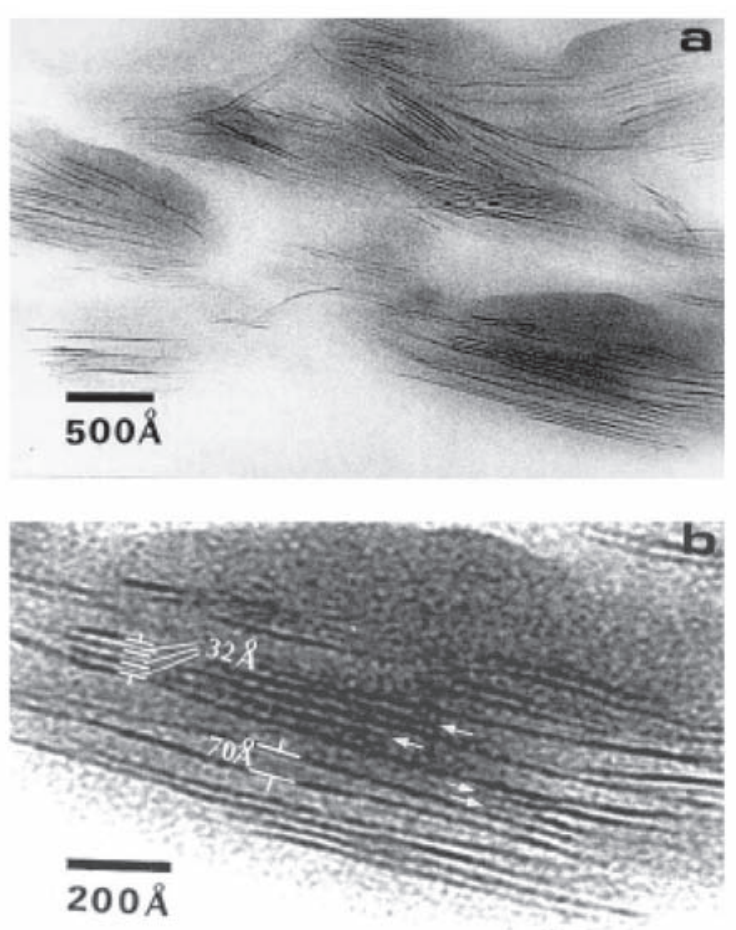

Figura 13: Micrografias obtidas por microscopia eletrônica de transmissão da esmectita intercalada com brometo de hexadecil trimetil amônio em concentração de 2,5 vezes a CTC: a) imagem mostrando cristalitos dispersos que contém várias camadas expandidas; b) ampliação de parte da imagem (a) mostrando a espessura de camadas expandidas [52].

[Figure 13: TEM micrographs of hexadecyl trimethyl ammoniumsmectite (2.5 CEC): a) an image showing dispersed crystallites that contain the various expanded layers; $b$ ) enlargement of part of (a) showing the thickness of expanded interlayers [52].]

intercalação de um sal quaternário de amônio é mais fácil em uma montmorilonita sódica do que em uma montmorilonita cálcica.

\section{Medida de área específica}

A cinética de todos os processos de interação heterogênea "sólido-fluido" depende da área especifica do reagente sólido. A medida da área especifica de argilas é importante porque permite avaliar transformações estruturais ocorridas em processos de modificação de argila, porém é pouco relatada na literatura sobre argilas organofílicas. A obtenção da medida da área especifica é baseada na análise de isotermas de adsorção-dessorção na temperatura de nitrogênio líquido e é geralmente obtida por dois métodos clássicos: BET (Brunauer, Emmett e Teller) e o modelo de Langmuir. Outros métodos também são empregados como, por exemplo, o BJH (Barrett, Joyner e Halenda) que permite o levantamento do tamanho médio e da distribuição de tamanho dos poros com a área especifica [54]. Foi efetuada troca de cátions cálcio de uma bentonita por cátions sódio através de tratamento com solução de cloreto de sódio, mediram a área específica 
pelo método etilenoglicolmonoetileter e foi observado que a área específica superficial da argila aumentou após a troca de cátions [55]. Com o método BET foram avaliadas as áreas especificas de bentonita sódica e bentonitas organofílicas modificadas com os sais brometo de tetradecil trimetil amônio e brometo de hexadecil trimetil amônio em concentrações equivalentes a $50 \%$ e $100 \%$ da capacidade de troca de cátions da argila. As áreas especificas encontradas para a bentonita sódica e para as bentonitas modificadas com os respectivos sais a $50 \%$ da capacidade de troca de cations foram 30,13 e $10 \mathrm{~m}^{2} / \mathrm{g}$, respectivamente. As áreas especificas das bentonitas modificadas com os dois sais na concentração de $100 \%$ da capacidade de troca de cátions foram muito pequenas e não puderam ser determinadas. Isso ocorre porque os agregados dos sais quaternários de amônio impedem a entrada de moléculas de nitrogênio [23]. O método BET também foi utilizado em [22] onde encontraram a área especifica de $28 \mathrm{~m}^{2} / \mathrm{g}$ para uma bentonita natural e 71 $\mathrm{m}^{2} / \mathrm{g}$ para uma bentonita modificada com tetraetil amônio. Porém, o mesmo autor citado em [22] encontrou uma área específica de $18 \mathrm{~m}^{2} / \mathrm{g}$ para uma montmorilonita modificada com brometo de tetrabutil amônio [56]. Os resultados encontrados na literatura mostram que pode ocorrer aumento da área específica em alguns casos, mas há uma tendência de redução da área especifica das argilas após tornaremse organofílicas. Porém, na literatura não são encontradas explicações detalhadas sobre as variações citadas.

\section{Análise térmica}

\section{Calorimetria diferencial de varredura}

A técnica de DSC permite acompanhar transformações que as argilas sofrem durante a queima e também a estabilidade térmica de argilas na forma organofílicas e dos compostos orgânicos intercalados, porém é pouco utilizada.

A técnica de DSC para foi empregada para avaliar a estabilidade térmica dos compostos amarelo de metanil (pfenilamina-azo-benzeno-3-benzeno sulfonato de sódio), paminodifenilamina e benzidina que foram intercalados em montmorilonita sódica. As análises foram realizadas na faixa de temperatura de $25-750{ }^{\circ} \mathrm{C}$ em atmosfera de nitrogênio e mostraram que os compostos orgânicos têm alta estabilidade térmica após a intercalação. Os resultados mostraram picos endotérmicos a 403,510 e $574{ }^{\circ} \mathrm{C}$ para amarelo de metanil, p-aminodifenilamina e benzidina, respectivamente, intercalados na argila [57].

\section{Análise termogravimétrica}

A análise termogravimétrica é útil para avaliar a quantidade e a decomposição do composto orgânico intercalado e também as etapas de desidratação e decomposição da argila. Análises termogravimétricas de alta resolução realizadas em montmorilonita modificada com brometo de octadecil trimetil amônio mostraram que a decomposição térmica ocorre em quatro etapas: dessorção de água que

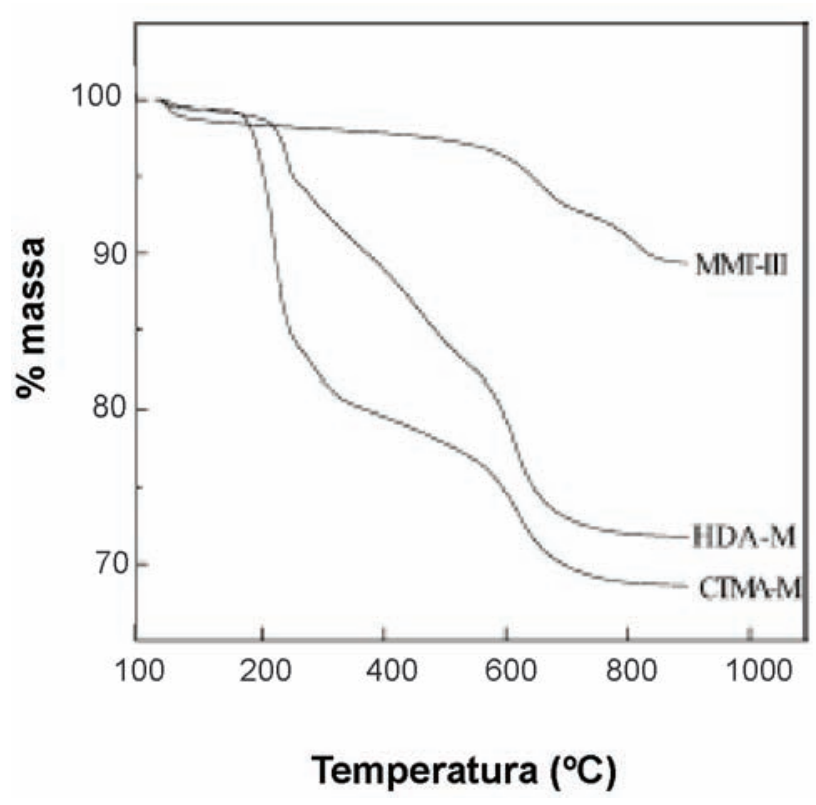

Figura 14: Curvas termogravimétricas da montmorilonita sódica (MMT-III), montmorilonita intercalada com sal de hexadecilamina (HDA-M), e montmorilonita intercalada com brometo de cetil trimetil amônio (CTMA-M) [55].

[Figure 14: Thermogravimetric curves of sodium bentonite (MMTIII), bentonite intercalated with 1-hexadecylamine salt (HDA-M) and bentonite intercalated with cetyl trimethyl ammonium bromide.]

ocorreu a temperatura ambiente; desidratação na faixa de temperatura de $87,9-135,5^{\circ} \mathrm{C}$ atribuída à perda de água dos cátions interlamelares; processo de decomposição do surfactante que ocorreu entre $178-384,5^{\circ} \mathrm{C}$ e desidroxilação de $\mathrm{OH}$ da argila na faixa de temperatura de $556-636,4^{\circ} \mathrm{C}$ [37]. Com a técnica de TGA foi verificada a quantidade dos sais derivados de 1-hexadecilamina e 1-octadecilamina, e os sais brometo de cetil trimetil amônio e brometo de octadecil trimetil amônio intercalados em montmorilonita sódica. As análises foram realizadas com faixa de temperatura que variou da temperatura ambiente a $900{ }^{\circ} \mathrm{C}$ com taxa de aquecimento de $10{ }^{\circ} \mathrm{C} / \mathrm{min}$ em atmosfera de nitrogênio de $5 \mathrm{~mL} \cdot \mathrm{min}^{-1}$. Os termogramas obtidos estão na Fig. 14 [55]. Os resultados obtidos também apresentaram as etapas características citadas anteriormente [37].

A montmorilonita sódica perdeu 2,6\% de massa na faixa de temperatura de $40-140{ }^{\circ} \mathrm{C}$ e $8 \%$ na faixa de $550-900{ }^{\circ} \mathrm{C}$. A primeira perda de massa observada é devido à evaporação de moléculas de água que são adsorvidas nos cátions interlamelares da bentonita e a segunda perda é relacionada à desidratação de moléculas de água do retículo cristalino. Nas argilas organofílicas intercaladas com o sal de hexadecilamina e brometo de cetil trimetil amônio ocorreu perda de água de dessorção de $0,6 \%$ e uma grande perda de massa na faixa de temperatura de $200-550{ }^{\circ} \mathrm{C}$ proveniente da decomposição dos sais de amônio. A massa perdida acima de $550{ }^{\circ} \mathrm{C}$ foi maior do que na montmorilonita sódica e isso é devido a perdas das moléculas de água por desidratação somada a queima do carbono residual do sal [55]. Entre os quatro sais utilizados, 
foi observado que a quantidade de sal intercalada aumentou com o aumento do peso molecular. As porcentagens em massa de sal intercalado foram de 17,5, 17,9, 20,6 e 21,6\%, para os sais de hexadecilamina, octadecilamina, brometo de cetil trimetil amônio e brometo de octadecil trimetil amônio, respectivamente [55]. Pontos de dessorção para montmorilonita modificada com brometo de tetrabutil amônio foram encontrados nas temperaturas de 95,6, 233,7, 360,4, $434,2,545,2$ e $664,6^{\circ} \mathrm{C}$ e sugeriu que os picos são atribuídos a dessorção de água fisicamente adsorvida e desidroxilação da camada de alumina. Outras possibilidades sugeridas para os picos a 360,4 e $434,2{ }^{\circ} \mathrm{C}$ é que sejam provenientes da decomposição dos íons butil amônio, enquanto os picos a 545,2 e $664,6{ }^{\circ} \mathrm{C}$ podem ser atribuídos a desidroxilação e a água e dióxido de carbono produzidos do resíduo carbonaceo formado após a decomposição dos íons butil amônio [56].

\section{Outras técnicas}

\section{Ressonância magnética nuclear}

A ressonância magnética nuclear é uma técnica que permite a análise de troca de cátions em argilas e também permite a realização de um estudo detalhado a respeito da estrutura e dinâmica de moléculas orgânicas confinadas nas galerias da argila. São utilizadas análises de $\mathrm{RMN}{ }^{13} \mathrm{C}$, RMN ${ }^{23} \mathrm{Na}, \mathrm{RMN}{ }^{29} \mathrm{Si}$ e RMN ${ }^{27} \mathrm{Al}$. Análise de RMN ${ }^{29} \mathrm{Si}$ foi utilizada para montmorilonita intercalada com sal de amônio e foi observado que os cátions de amônio adsorvidos na superfície da argila induzem a uma considerável blindagem do núcleo [58]. Pelos espectros de $\mathrm{RMN}{ }^{23} \mathrm{Na}$ foi observado que íons sódio trocáveis em mica sintética fluorotetrasilicia sódica somente podem ser substituídos por íons alquilamônio se estes estiverem presentes em excesso e com o processo repetitivo de troca de íons [18]. A análise $\mathrm{RMN}{ }^{13} \mathrm{C}$ forneceu informações sobre o ambiente molecular e as propriedades dinâmicas de cátions cetil trimetil amônio intercalados em montmorilonita. As diferentes mobilidades dos átomos de carbono do cátion orgânico que foram identificadas com a análise levaram a conclusão de que não há um completo estado do tipo sólido para os surfactantes intercalados [35].

\section{Energia dispersiva de raios $X$}

A técnica de energia dispersiva de raios $\mathrm{X}$ é útil na análise da composição da argila, porém também é uma técnica pouco relatada na literatura. Análises de EDX foram utilizadas para investigar qualitativamente as variações de composição de uma esmectita após modificação com brometo de hexadecil trimetil amônio. A análise mostrou que o sódio é detectado como traços superficiais confirmando que a maioria dos cátions sódio foram trocados pelos cátions de amônio [52].

\section{CONCLUSÕES}

A inserção de moléculas orgânicas em argilas torna a argila organofílica, e proporciona diversas possibilidades de aplicações das mesmas. A estrutura e o tamanho das moléculas orgânicas usadas na modificação, a densidade e orientação dessas moléculas sobre a superfície das argilas são fatores importantes que definem as características das argilas organofílicas.

O estudo de argilas organofílicas é um campo bastante amplo e mostra que tem grande potencial a ser explorado. Embora já exista uma vasta literatura que propõem o uso de diferentes argilas, com diversos procedimentos de obtenção deste tipo de material, bem como diferentes aplicações, muitos estudos ainda podem ser feitos no sentido de buscar e classificar melhor os tipos de argilas que podem ser modificadas, definir parâmetros de processamento com mais precisão, criar rotas alternativas de preparação, e estudar melhorias nas propriedades dos materiais obtidos através da comparação de diferentes compostos de modificação e metodologias de preparação em função da aplicação requerida.

\section{AGRADECIMENTOS}

Ao CNPq pelo apoio financeiro.

\section{REFERÊNCIAS}

[1] A. P. Chagas, Argilas: as essências da terra, Editora Moderna, S. Paulo (1996).

[2] P. S. Santos, Ciência e Tecnologia de Argilas, $2^{\mathrm{a}}$ Edição, Editora Edgard Blucher, S. Paulo (1989) 66-68.

[3] A. S. Filho, Diss. Mestrado, Universidade Estadual de Campinas (1998).

[4] C. P. F. Santos, D. M. A. Melo, M. A. F. Melo, E. V. Sobrinho, Cerâmica 48, 308 (2002)178.

[5] F. Bergaya, G. Lagaly, Appl. Clay Sci. 19 (2001) 1.

[6] D. Merinska, Z. Malac, M. Pospisil, Z. Weiss, M. Chmielova, P. Capkova, J. Simonik, Comp. Interf. 9 (2002) 529.

[7] N. Kakegawa, M. Ogawa, Appl. Clay Sci. 22 (2002) 137.

[8] R. K. Bharadwaj, Macromolecules V (2001) 9189.

[9] G. Lagaly, S. Ziesmer, Adv. Col. and Int. Sci. 100-102 (2003) 105.

[10] L. A. Utracki,Clay Containing Polymeric Nanocomposites, Rapra Technology (2004).

[11] M. Alexandre, P. Dubois, Mater. Sci. Eng. 28 (2000)1.

[12] D. Vougaris, D. Petridis, Polymer 43 (2002) 2213.

[13] G. Gorassi, M. Tortora, V. Vittoria, D. Kaempfer, R. Mülhaupt, Polymer 44 (2003) 3679.

[14] S. Akyüz, T. Akyüz, J. Mol. Struc. 651-653 (2003) 205.

[15] K. Tamura, H. Nakazawa, Clays Clay Min. 44 (1996) 501.

[16] Z. Klapyta, T. Fujita, N. Iyi, Appl. Clay Sci. 19 (2001) 5.

[17] J. H. Chang, Y. Uk An, D. Cho, E. P. Giannelis, Polymer 44 (2003) 3715.

[18] Z. Klapyta, A. Gawel, T. Fujita, N. Iyi, Clay Min. 38 (2003)151. 
[19] J. Markarian, Plastics Additives \& Compounding (1112/2005) 18.

[20] G. Chigwada, C. A. Wilkie, Pol. Degrad. Stab. 3 (2003), 551.

[21] T. Kwolek, M. Hodorowicz, K. Stadmicka, J. Czapkiewicz, J. Coll. Interf. Sci. 264 (2003) 14-19.

[22] M. Akçay, J. Coll. Interf. Sci. 280 (2004) 299.

[23] N. Yilmaz, S. Yapar, Appl. Clay Sci. 27 (2004) 223.

[24] S. Yapar, V.Özbudak, A. Lopes, J. Hazardous Mater. 121 (2005) 135.

[25] G. W. Beall, M. Goss, Appl. Clay Sci. 27 (2004) 179.

[26] Y. Xi, Z. Ding, H. He, R. L. Frost, Spectrochim. Acta Part A 61 (2005) 515.

[27] S. S. Araújo, D. L. A. C. S. Andrade, L. H. Carvalho, A. S. Gomes, S. M. L. Silva, Plást. Ind. (12/2005) 104.

[28] F. R. V. Díaz, Tese de Doutorado, Universidade de S. Paulo, S. Paulo (1994).

[29] Y-Q. Zhang, J-H. Lee, J. M. Rhee, K. Y. Rhee, Comp. Sci. Tech. 64 (2004) 1383.

[30] R. A. Vaia, R. K. Teukolsky, E. P.Giannelis, Chem. Mater. 6 (1994) 1017.

[31] V. N. Moraru, Appl. Clay Sci. 19, 11-26 (2001) 1918.

[32] S-J. Park, D. Il Seo, J-R. Lee, J. Coll. Interf. Sci. 251 (2002) 160.

[33] M. Arroyo, M. A. López-Manchado, B. Herrero, Polymer 44 (2003) 2447.

[34] H. Hongping, F. Ray, Z. Jianxi, Spectrochim. Acta Part A 60 (2004) 2853.

[35] M. Kozak, L. Domba, J. Phys. Chem. Sol. 65 (2004) 441.

[36] M. Majdan, O. Maryuk, S. Pikus, E. Olszewska, R. Kwiatkowski, H. Skrzypek, J. Mol. Struct. 70 (2005) 203.

[37] Y. Xi, Z. Ding, H. He, R. L. Frost, J. Coll. Interf. Sci. 277 (2004) 116.

[38] J. Zhu, H. He, X. Wen, F. Deng, J. Coll. Sci.Interf. Sci. 286 (2005) 239.

[39] S. Yoshimoto, F. Osashi, T. Kameyama, Solid State
Comm. 136 (2005) 251.

[40] P. C. LeBaron, Z. Wang, T. J. Pinnavaia, Appl. Clay Sci. 15 (1999) 11.

[41] E. Hackett, E. Manias, E. P. Giannelis, J. Chem. Phys. 108 (1998) 7410.

[42] R. Morrison, R. Boyd, Química Orgânica, Fund. Calouste Gulbenkian, Lisboa (1996) 960.

[43] X. Liu, Q. Wu, Polymer 42 (2001) 10013-10019.

[44] Y. H. Shen, Chemosphere 44 (2001) 989.

[45] H. Yao, J. Zhu, A. B. Morgan, C. A. Wilkie, Polym. Eng. Sci. 42 (2002) 1808.

[46] W. H. Awad, J. W. Gilman, M. Nuden, R. H. Harris, Jr., T. E. Sutto, J. Callahan, P. C. Truvole, H. C. DeLong, D. M. Fox, Thermochim. Acta 409 (2004) 3.

[47] Y-Q.Zhang, J-L. Lee,H-J.Jang, C.-W.Nah, Composites: Part B 35 (2003) 133.

[48] A. Sánchez-Sólis, I. Romero-Ibarra, M. R. Estrada, F. Calderas, O. Manero, Polym. Eng. Sci. 44 (2004) 1094.

[49] H. He, J. Duchet, J. Galy, J.-F. Gerard, J. Coll. Interf. Sci. 288 (2005) 171.

[50] A. Pozsgay, T. Cráter, L. Százdi, P. Müller, I. Sajó, B. Pukánszky, Europ. Polym. J. 40 (2003) 27.

[51] W. Shishan, J. Dingjun, O. Xiaodong, W. Fen, S. Jian, Polym. Eng. Sci. 44 (2004) 2070.

[52] S. Y. Lee, S. J. Kim, Coll. Surf. A: Physicochem. Eng. Aspects 211 (2002) 19.

[53] S. Y. Lee, W. J. Cho, K. J. Kim, J. H. Ahn, M. Lee, J. Coll. Interf. Sci. 284 (2005) 667.

[54] M. R. M. P. Aguiar, A. C. Novaes, Quím. Nova 25 (2003) 1145.

[55] J. Y. Lee, H. K. Lee, Mater. Chem. Phys. 85 (2004) 41. [56] M. Akçay, J. Coll. Interf. Sci. 296 (2006) 16.

[57] A. H. Gemeay, A. S. El-Sherbing, A. B. Zaki, J. Coll. Interf. Sci. 245 (2005) 116.

[58] I. K. Breakwell, J. Homer, M. A. M. Lawrence, W. R. Mcwhinnie, Polyhedron 14 (1995) 2511.

(Rec. 18/06/2007, Ac. 14/12/2007) 